\title{
Chinese Chestnut (Castanea mollissima) as a Niche Crop in the Central Region of the United States
}

\author{
Michele R. Warmund \\ Division of Plant Sciences, University of Missouri, 1-31 Agriculture Building, Columbia, MO 65211-7140
}

Additional index words. flowering, grafting, production, pests, thinning

\begin{abstract}
Chinese chestnut (Castanea mollissima Blume) is an exotic species that has potential as a niche crop. As a nut crop, it is relatively precocious in its bearing habit and has resistance to chestnut blight, tolerance to low winter temperatures, and relatively few pests. Current prices for fresh chestnuts are as much as $\$ 14 / \mathrm{kg}$. Most U.S. chestnut growers (64\%) have small orchards (less than $4 \mathrm{ha}$ ) and have been producing this crop for less than 10 years. Commercial chestnut production is low $(\approx 680,000 \mathrm{~kg})$ in the United States, but it is a relatively new industry in the central region. Limitations to growing this crop include a shortage of grafted trees, high tree costs, low yield efficiency, and high labor costs resulting from limited large-scale harvest equipment in the United States. However, results of ongoing research using cultivars on dwarfing rootstocks, thinning of secondary $\left(2^{\circ}\right)$ flowers, and improved tree nutrition will likely enhance profitability of production. In a 2003 Missouri survey, $67 \%$ of those interviewed had never consumed Chinese chestnuts but associated chestnut roasting with holidays. Chinese chestnuts provide health benefits. including a source of dietary fiber, a significant amount of vitamin $\mathrm{C}$, no cholesterol, and are gluten-free.
\end{abstract}

Although early poetry from 1000 to 500 B.C. chronicles Chinese chestnut as an economic crop in northern China, it was introduced into the United States in 1853 (Keng, 1974; McKay and Berry, 1960). Early interest in this species was for timber production and resistance to chestnut blight rather than for nut production (Payne et al., 1983). Today, U.S. chestnut production is less than $1 \%$ of that produced worldwide [U.S. Department of Agriculture (USDA) Foreign Agricultural Serv., 2008]. Most of the 1350 ha of chestnuts produced in the United States are grown in Michigan, California, Oregon, Florida, and Ohio (USDA, 2007). Only 35 ha of chestnut trees are currently grown in Iowa, Illinois, Missouri, and Kansas with unmet demand for this crop (Gold et al., 2006). In 2008, 4122 t of chestnuts were imported into the United States, primarily from China, Italy, and the Republic of Korea (USDA Foreign Agricultural Serv., 2008).

Most U.S. chestnut orchards are small (less than 4 ha) and $64 \%$ of the growers have been producing this crop for less than 10 years (Gold et al., 2006). Production is low $(680,388$ $\mathrm{kg}$ ), but many of the trees are in the early stages of bearing a commercial crop. In Missouri, it is projected that 40 ha of Chinese chestnut trees will be planted within the next 2 years (M.A. Gold, personal communication).

Currently, several different types of chestnuts are commercially grown and marketed in the United States, including cultivars and seedlings of Chinese chestnut (Castanea mollissima B1.), European chestnut (C. sativa Mill.), and interspecific hybrids of European and Japanese (C. crenata Sieb. \& Zucc.)

\footnotetext{
Received for publication 25 Aug. 2010. Accepted for publication 22 Sept. 2010.

Contribution from the Missouri Agricultural Station project 322 .

This paper was part of the workshop "Advances in Specialty Nut Crops" held 25 July 2009 at the ASHS Conference, St. Louis, MO, and sponsored by the Temperate Tree Nut Crops (NUTS) Working Group. e-mail warmundm@missouri.edu.
}

chestnuts (Anagnostakis, 2008). Additionally, cultivars of interspecific hybrids that include Chinese, Japanese, and American ( $C$. dentata Borkh) species in their pedigree have been planted. European chestnut cultivars and 'Colossal' (C. sativa $\times$ C. crenata) are grown in primarily in the western United States, whereas a mix of the previously listed species are grown in other U.S. regions.

\section{POTENTIAL FOR EXPANDED CHINESE CHESTNUT PRODUCTION}

Because there is little competition among growers in the United States, there is potential for expanded production as a result of strong consumer preference to buy local as well as unmet demand (Olsen, 2000). In the central region of the United States, Chinese chestnut is recommended as a result of its tolerance to $-30{ }^{\circ} \mathrm{C}$ in midwinter and its superior resistance to chestnut blight fungus [Cryphonectria parasitica (Murrill) Barr] as compared with other Castanea species (Miller, 2007; Payne et al., 1983). Blight-susceptible American chestnut trees produce small nuts ( 4 to $5 \mathrm{~g}$ ) as compared with those from Chinese, European, and Japanese trees. European chestnut trees are generally less cold-hardy with some selections surviving $-20{ }^{\circ} \mathrm{C}$ and are more susceptible to chestnut blight and ink disease [Phytopthora cambivora (Petri) Buisman and P. cinnamomi Rands] than Chinese chestnut trees.

Grafted trees of Chinese chestnut are relatively more precocious than seedlings with commercial bearing in 5 to 10 years after planting. Twelve- to 15 -year-old commercial orchards produce $224 \mathrm{~kg} \cdot \mathrm{ha}^{-1}$ (Hunt et al., 2005). Chinese chestnut trees have been relatively free of serious pests in the midwestern and western regions of the United States. However, in 1974, the Asian or Oriental gall wasp [Dryocosmus kuriphilus (Yasumatsu)] was introduced into Georgia (Cooper and Rieske, 2007). Chestnut gall wasp has now been identified in other states, including Alabama, North Carolina, Virginia, Maryland, Pennsylvania, Maryland, Kentucky, Tennessee, and Ohio. Although the chestnut gall wasp has not been found in the central region of the United States, infestations will likely occur in this area in the near future as the distribution of this pest has been attributed primarily to the transport of infested seedlings to new areas and the exchange of infested scion wood used to graft trees (Rieske, 2007). In May 2010, the Michigan Department of Agriculture established a plant pest quarantine against the chestnut gall wasp, restricting the movement of nursery stock from previously listed states. Currently, chemical controls of this pest are not feasible on trees where nuts are harvested for human consumption. Other pests include the potato leafhopper [Empoasca fabae (Harris)], which feeds on chestnut foliage in May and June, lesser chestnut weevils [Curculio sayi (Gyllenhal)], and larger chestnut weevils [C. caryatrypes (Boheman)] (Payne et al., 1983). Prompt harvest and removal of lateripening secondary $\left(2^{\circ}\right)$ nuts from the orchard minimizes weevil damage and prevents future build-up of the weevil population (Hunt et al., 2009; Keesey and Barrett, 2008).

Post-harvest handling of chestnuts is minimal because nuts are immediately washed, dried to remove surface moisture, bagged, and cold-stored at -2 to $0{ }^{\circ} \mathrm{C}$ for storage up to 3 months. For longer storage, disinfectant treatments such as chlorination with sodium hypochlorite, hydrogen peroxide, sorbic, propionic or peracetic acid, natamycin, or ozonation have been used to prevent molds (Panagou et al., 2005). Most chestnuts are sold in-shell with retail prices for fresh chestnuts as much as $\$ 14 / \mathrm{kg}$ (Gold et al., 2006). In Michigan, frozen peeled chestnuts in vacuum-packed pouches are marketed to chefs and other buyers (Fulbright et al., 2003).

Chestnuts are a nutritious food because they are a source of dietary fiber, a significant amount of vitamin $\mathrm{C}$, but no cholesterol or gluten (University of Missouri, 2008). Unlike other nuts, chestnuts are low in fat with $2 \mathrm{~g}$ total fat per $84-\mathrm{g}$ serving. Chestnut can be dried and ground into flour as an alternative to wheat, barley, and rye flour for those with gluten intolerance. Other value-added products such as ready-to-use chestnuts and dehydrated 
chestnut chips have recently been developed in Michigan.

\section{LIMITATIONS OF CHINESE CHESTNUT PRODUCTION}

Although there is potential for expanded Chinese chestnut production, there are limitations to growing this crop, including a paucity of commercially grafted trees, high tree costs, prolific late-season $2^{\circ}$ flowering and nut production for several cultivars, susceptibility of buds on terminal shoots to late spring frosts, low yield efficiency, high labor costs associated with hand harvesting, and lack of long-term research in the United States. There are relatively few nurseries producing grafted Chinese chestnut trees and tree costs are high ( $\$ 16$ to 20 per tree) as compared with other fruit and nut trees (Hunt et al., 2009). Because the chestnut gall wasp has spread to many of the states where nurseries are located, the supply of scion wood originating from non-infested locations is scarce. Grafting failure or low percentages of successful graft unions have also limited availability of chestnut trees (Huang et al., 1994; Warmund and Coggeshall, 2009). Graft union formation is enhanced when budding is done in the latter part of September as compared with budding dates in late July or August. Whip-and-tongue grafting in early spring produces higher percentages of successful unions than budding (M.R. Warmund and M.V. Coggeshall, unpublished data). Low rootstock moisture content at the time of grafting also enhances graft union formation. In Missouri, 'AU-Cropper' seedlings are the standard vigorous rootstocks used for commercial plantings of Chinese chestnut trees. Jaynes (1979) recommended grafting a chestnut cultivar onto seedling rootstock derived from the same cultivar to avoid incompatibility and to enhance successful union formation.

The production of $2^{\circ}$ flowers on some Chinese chestnut cultivars can be problematic. In Missouri, the first flowering generally occurs in June. Bisexual catkins are produced distally on the current season's shoot and unisexual male catkins develop proximally on the same shoot. Bisexual catkins produce pistillate flowers proximally, which develop into primary $\left(1^{\circ}\right)$ burs (involucres). A second flowering period occurs in late July or early August after a second flush of vegetative growth. After pollination, nuts are also produced within these lateseason $2^{\circ}$ burs. However, $2^{\circ}$ nuts do not often attain sufficient size for the retail market by the end of the growing season (Warmund et al., 2005). Also, limb breakage occurs with a heavy load of $2^{\circ}$ burs on the terminal shoots. Threeyear evaluations have shown that cultivars such as 'Peach', 'Qing', 'Simpson', 'Carr', 'AU-Homestead', and 'Gideon' produce few $2^{\circ}$ burs from late July through early November (Warmund et al., 2010). In contrast, 'Armstrong', 'AU-Cropper', 'Carolina', 'Crane', 'Eaton', 'Ford's Tall', 'Jersey Gem', 'Orrin', 'Mossbarger', 'Revival', and 'Willamette' produce many $2^{\circ}$ burs. 'Willamette' trees produced as many as $282^{\circ}$ burs per shoot in several years (M.R. Warmund, unpublished data).
In a recent study (Warmund et al., 2010), hand removal of $2^{\circ}$ burs on 'Peach' trees enhanced $1^{\circ}$ nut weights at harvest as well as $1^{\circ}$ bur production in the next season. However, this practice is not economically feasible and thinning treatments with Fruitone ${ }^{\circledR} \mathrm{N}$ (sodium salt of 1-naphthalenaecitic acid), accel [N(phenylmethyl)-1 H-purine-6-amine + gibberellins $\left.\mathrm{A}_{4}+\mathrm{A}_{7}\right)$ ], and carbaryl (1-naphthyl Nmethylcarbamate) did not remove newly formed $2^{\circ}$ burs when applied in early August (M.R. Warmund, unpublished data). Other researchers applied various chemical growth regulators to thin catkins produced early in the growing season (Feng, 1995; Kuiying and Zongyun, 2009; Wei, 1994; Zongyun and Kuiying, 2009). These reports demonstrate that thinning or removal of catkins in the spring is a strategy that can be used to enhance total $1^{\circ}$ nut weight, average $1^{\circ}$ nut weight at harvest, and the production of $1^{\circ}$ burs in the next season, but the effect of these treatments on $2^{\circ}$ flowering and nut production was not reported. Effective strategies have not yet been developed for managing $2^{\circ}$ flowering. However, studies to elucidate environmental conditions that enhance or diminish $2^{\circ}$ nut production are in progress.

Chestnut production in the central region of the United States can be affected occasionally by spring frosts (Warmund et al., 2010). However, some cultivars are more tolerant to late spring frosts than others. For example, after the third warmest March in 118 years, an unprecedented freeze event occurred in which temperatures dropped to $-8{ }^{\circ} \mathrm{C}$ during 4 to 7 Apr. 2007. After the freeze, 'Willamette' trees had more $1^{\circ}$ flower and bur loss than later flowering 'Orrin' trees (Warmund et al., 2010). Although $1^{\circ}$ bur numbers were reduced by spring cold temperatures, a substantial number of $2^{\circ}$ burs was produced on 'Willamette' trees later in the growing season and a marketable crop of $2^{\circ}$ nuts was harvested. Therefore, in areas where spring frosts are likely, cultivars that break bud and produce $1^{\circ}$ flowers later can be planted. Alternatively, frost-susceptible cultivars with prolific $2^{\circ}$ flowers can be grown to produce a crop from $2^{\circ}$ burs with small nut size.

Another limitation to the profitability of Chinese chestnut production is low yield efficiency. Mature trees are 12 to $15 \mathrm{~m}$ at maturity. The tall tree canopy also makes training, pruning, and pest control difficult and incurs high labor costs. Thus, the use of dwarfing rootstocks might be a way to reduce production costs and thereby increase profitability. Dwarfing rootstocks not only affect tree size, but also influence anchorage, disease susceptibility, precocity, and soil and climatic adaptability in fruit crops (Rom and Carlson, 1987). Recently 'Little Giant', 'Hope', and 'King Arthur' (complex hybrids of C. mollissima $\times C$. seguinii Dode), provided by the Connecticut Agricultural Experiment Station, were identified as potential sources of genetic dwarfing to increase tree densities and yield in orchards. Seedling rootstocks of these cultivars were grown and grafted in 2008. Interstems from 'Little Giant' seedlings were also grafted onto 'AU-Cropper' seedling rootstocks with 'Eaton' or 'AU-Super' scions in 2006. These trees are currently being evaluated for 10 years in a replicated trial at the University of Missouri Horticulture and Agroforestry Research Center (HARC), New Franklin, MO.

The lack of harvest equipment for use in sod-covered orchard floors is another limiting factor to profitable Chinese chestnut production. In Europe, large-scale harvest equipment for use in sod-covered orchards is available but is cost-prohibitive for small chestnut orchards. In the Pacific Northwest region of the United States, where sod is not used on the orchard floor, Weiss McNair hazelnut sweepers and harvesters (Chico, CA) are used for chestnuts. However, these types of harvesters designed for other nut crops fail to pick up many of Chinese chestnuts that have a flat surface on one or both sides of the nut and are buried in sod. Researchers at Michigan State University are currently developing chestnut harvest equipment (D.W. Fulbright, personal communication). Low-cost modified pasture vacuums (Greystone Paddock Vac, Zephyrhills, FL) are also being evaluated in time and motion studies for use in small chestnut orchards at the University of Missouri.

The paucity of long-term research conducted with Chinese cultivars grown in the United States has limited progress with this crop. Although the first cultivar selections of Chinese chestnut for nut production were made in 1930 (Reed, 1946), a current largescale collection of Chinese chestnut is absent in the USDA national plant germplasm system. Repositories of 65 named Chinese chestnut cultivars were established at HARC in 1996. Although evaluation of fruiting and vegetative characteristics of these trees is ongoing, current recommended cultivars include 'AU-Homestead', 'Eaton', 'Gideon', 'Peach', and 'Sleeping Giant' (Hunt et al., 2005, 2009). Most of these cultivars are harvested in mid-September to early October in Missouri with nut size ranging from 59 to 84 nuts $/ \mathrm{kg}$. Currently, identities of cultivars at HARC are being confirmed by DNA "fingerprinting" using a series of seven single sequence repeat microsatellite markers. In many orchards, chestnut cultivar identities are unknown or may be misnamed as a result of the exchange of scion wood among producers who have propagated their own trees.

Research-based information on Chinese chestnut tree nutrition is also lacking. Currently, pre-plant soil fertility and foliar nutrient recommendations are based on data obtained from other fruit and nut crops (Hunt et al., 2009; Vossen, 2000). In Missouri, five different levels of nitrogen are being evaluated to determine which level provides a yield response. When this is determined, a sufficiency range of foliar nitrogen can be recommended. Earlier work demonstrated that SPAD-502 chlorophyll meter readings had the strongest relationship to foliar nitrogen when midshoot leaves from a current season's growth were sampled in mid-June (Warmund, 2009). Thus, the SPAD meter may be a promising tool for the rapid assessment of foliar nitrogen of 
Chinese chestnut trees and for the diagnosis of nitrogen deficiency in the future.

Consumer familiarity with Chinese chestnut is low with limited knowledge about how to purchase quality nuts, their preparation, and nutritional properties (Gold et al., 2004, 2005). In two surveys, over $70 \%$ of respondents indicated that taste was the most important factor that influenced their decision to purchase chestnuts. Although sweetness is frequently evaluated in sensory studies with chestnuts, lexicon development (to describe flavor and texture attributes) and descriptive analysis of Chinese, European, Japanese, and hybrids of these species are being conducted by trained panelists to guide cultivar selection and consumer acceptability of chestnuts grown in the United States (M.R. Warmund, unpublished data). With the identification of flavor descriptors, cultivars with specific attributes that may be perceived as unappealing by consumers could be eliminated from the marketplace.

\section{FUTURE OUTLOOK FOR CHINESE CHESTNUT PRODUCTION}

In two surveys, $64 \%$ of respondents indicated that they would like to purchase chestnuts two or more times per year (Gold et al., 2005). An increase in chestnut consumption has occurred among Missouri chestnut roast festival participants from 2003 to 2008 (Cernusca et al., 2008). The trend toward consumer preferences for locally grown produce also indicates new opportunities for Midwest chestnut growers. Consumer feedback revealed that chestnuts produced in Missouri are 20 times more likely to be chosen over imports (Aguilar et al., 2009). Based on the unmet demand, willingness of consumers to purchase chestnuts, and suitability of this crop for planting, there is potential for a niche market for Chinese chestnut in the central region of the United States. The University of Missouri Center for Agroforestry, Columbia, MO, has set a goal of 800 ha of Chinese chestnuts planted in Missouri by 2020. Based on economic projections, this would inject $\$ 4$ to 7 million for wholesale nuts and up to $\$ 20$ million for retail nuts into the economy (M.A. Gold, personal communication). Meanwhile, research in progress will provide some of the missing information that may further enhance the profitability of this crop.

\section{Literature Cited}

Aguilar, F.X., M.M. Cernusca, M.A. Gold, and C. Barbieri. 2009. Frequency of consumption, familiarity and preferences for chestnuts in
Missouri. Agroforestry Systems 79:19-29. 5 Sept. 2010. <http://www.springerlink.com/content/ a231078858417524/>.

Anagnostakis, S.L. 2008. Chestnut cultivar names A-Z. Connecticut Agricultural Experiment Station, New Haven, CT. 3 Jan. 2009. < http://www. ct.gov/caes/cwp/view.asp?a=2815\&q=376864>.

Cernusca, M.M., M.A. Gold, and L.D. Godsey. 2008 Influencing consumer awareness through the Missouri chestnut roast. J. Ext. 46:1 Nov. 2009. $<$ http://www.joe.org/joe/2008december/rb7p. shtml>.

Cooper, W.R. and L.K. Rieske. 2007. Community associates of an exotic gallmaker, Dryocosmus kuriphilus (Hymenoptera: Cynipidae), in Eastern North America. Ann. Entomol. Soc. Amer. 100:236-244.

Feng, Z.Q. 1995. Study of reason on thinning catkins in Chinese chestnut. Chinese Fruit 1:14-15.

Fulbright, D.W., M. Mandujano, B. Smith, and T. Kalchik. 2003. An overview of the emerging chestnut industry in Michigan. Northern Nut Grower Annu. Rpt. 94:9-13.

Gold, M.A., M.M. Cernusca, and L.D. Godsey. 2004. Consumer preferences for chestnuts, eastern black walnuts, and pecans. HortTechnology 14:583-589.

Gold, M.A., M.M. Cernusca, and L.D. Godsey. 2005. Update on consumers' preferences for chestnuts. HortTechnology 15:904-906.

Gold, M.A., M.M. Cernusca, and L.D. Godsey. 2006. Competitive market analysis: Chestnut producers. HortTechnology 16:360-369.

Huang, J., J.D. Norton, G.E. Boyhan, and B.R. Abrahams. 1994. Graft compatibility among chestnut (Castanea) species. J. Amer. Soc. Hort. Sci. 119:1127-1132.

Hunt, K., M. Gold, W. Reid, and M. Warmund. 2009. Growing Chinese chestnuts in Missouri. Univ. MO. Center for Agroforestry, Publ. AF1007.

Hunt, K.L., M.A. Gold, and M.R. Warmund. 2005. Chinese chestnut cultivar performance in Missouri. Acta Hort. 693:145-148.

Jaynes, R.A. 1979. Chestnuts, p. 111-127. In: Jaynes, R.A. (ed.). Nut tree culture in North America. Northern Nut Growers Assoc. Hamden, CT.

Keesey, I.W. and B.A. Barrett. 2008. Seasonal occurrence and soil distribution of the lesser chestnut weevil, Curculio sayi (Coleoptera: Curculionidae) in mid-Missouri. J. Kans. Entomol. Soc. 81:345-354.

Keng, H. 1974. Economic plants of ancient North China as mentioned in Shih Ching (Book of Poetry). Econ. Bot. 28:391-410.

Kuiying, L. and Z. Zongyun. 2009. Chemical thinning catkins in the Chinese chestnut. Acta Hort. 844:447-450.

McKay, J.W. and F.J. Berry. 1960. Introduction and distribution of Chinese chestnuts in United States. Northern Nut Growers Annu. Rpt. 67: 83-86.

Miller, G. 2007. Chestnuts, p. 167-181. In: Fulbright, D. (ed.). A guide to nut tree culture in North America. Vol. 1. McNaughton and Gunn, Saline, MI.
Olsen, J.L. 2000. Chestnut production in the northwestern United States. HortTechnology 10: 296-297.

Panagou, E.Z., S.A. Vekiari, P. Sourris, and C. Mallidis. 2005. Efficacy of hot water, hypochlorite, organic acids and natamycin in the control of post-harvest fungal infection of chestnuts. J. Hort. Sci. Biotechnol. 80:61-64.

Payne, J.A., R.A. Jaynes, and S.J. Kays. 1983. Chinese chestnut production in the United States: Practice, problems, and possible solutions. Econ. Bot. 37:187-200.

Reed, C.A. 1946. Status of Chinese chestnut growing in the eastern United States. Natl. Hort. Mag. 26:83-93.

Rieske, L.K. 2007. Success of an exotic gallmaker, Dryocosmus kuriphilus, on chestnut in the USA: A historical account. European \& Mediterranean Plant Protection Organization Bul. Wiley InterScience. 1 Nov. 2009. <http://www3.interscience. wiley.com/cgi-bin/fulltext/118486088/htmlstart>.

Rom, R.C. and R.F. Carlson. 1987. Rootstocks for fruit crops. John Wiley \& Sons, New York, NY.

U.S. Department of Agriculture. 2007. Census of agriculture, fruits and nuts. 18 Nov. 2009. <http:// www.agcensus.usda.gov/Publications/2007/Full_ Report/Volume_1_Chapter_2_US_State_Level/ st99_2_032_032.pdf $>$.

U.S. Department of Agriculture Foreign Agricultural Serv. 2008. U.S. trade imports-FATUS commodity aggregations. U.S. trade imports. 1 Nov. 2009. <http://www.fas.usda.gov/ustrade/ USTIMFatus.asp $>$.

University of Missouri. 2008. Why chestnuts? Center for Agroforestry. 1 Nov. 2009. <http://www. centerforagroforestry.org/pubs/whychestnuts. pdf $>$.

Vossen, P. 2000. Chestnut culture in California. Division of Agriculture and Natural Resources. Publ. 8010. University of California, Davis. 1 Nov. 2009. <http://ucanr.org/freepubs/docs/8010. pdf $>$.

Warmund, M.R. 2009. Fertilizer applications affect foliar nitrogen, chlorophyll, shoot growth and yield of 'Qing' Chinese chestnut. Acta Hort. 844:451-456.

Warmund, M.R. and M.V. Coggeshall. 2009. Chip budding of 'AU-Super' Chinese chestnut scions on AU-Cropper and Qing seedling rootstocks. Acta Hort. 844:115-118.

Warmund, M.R., D.J. Enderton, and J.W. Van Sambeek. 2010. Bur and nut production on three chestnut cultivars. J. Amer. Pomol. Soc. 64:110-119.

Warmund, M.R., K.L. Hunt, and M.A. Gold. 2005. Removal of secondary burs increases average nut weight from primary burs of 'Armstrong', 'Orrin' and 'Willamette' Chinese chestnuts. Acta Hort. 693:149-152.

Wei, Y.B. 1994. Effect of thinning catkins by manual. Hebei Fruit 1:36.

Zongyun, Z. and L. Kuiying. 2009. Effect of chemical thinning catkins on Chinese chestnut yield and quality. Acta Hort. 844:457-460. 